\title{
Transcriptomic analysis of Staphylococcus xylosus in the presence of nitrate and nitrite in meat reveals its response to nitrosative stress
}

\author{
Aurore Vermassen ${ }^{1}$, Anne de la Foye ${ }^{2}$, Valentin Loux ${ }^{3}$, Régine Talon ${ }^{1}$ and Sabine Leroy ${ }^{1 *}$ \\ ${ }^{1}$ Institut National de la Recherche Agronomique, UR454 Microbiologie, Saint-Genès-Champanelle, France \\ 2 Institut National de la Recherche Agronomique, Plateforme d'Exploration du Métabolisme, Saint-Genès-Champanelle, France \\ ${ }^{3}$ Institut National de la Recherche Agronomique, UR1077 Mathématique, Informatique et Génome, Jouy-en-Josas, France
}

\section{Edited by:}

Biswarup Mukhopadhyay, Virginia

Tech, USA

Reviewed by:

Yves Le Loir, Institut National de la Recherche Agronomique, France

Greg Somerville, University of

Nebraska, USA

*Correspondence:

Sabine Leroy, Institut National de la Recherche Agronomique, UR454

Microbiologie, 63122

Saint-Genès-Champanelle, France

e-mail: sabine.leroy@clermont.inra.fr
Staphylococcus xylosus is one of the major starter cultures used for meat fermentation because of its crucial role in the reduction of nitrate to nitrite which contributes to color and flavor development. Despite longstanding use of these additives, their impact on the physiology of $S$. xylosus has not yet been explored. We present the first in situ global gene expression profile of $S$. xylosus in meat supplemented with nitrate and nitrite at the levels used in the meat industry. More than 600 genes of $S$. xylosus were differentially expressed at 24 or $72 \mathrm{~h}$ of incubation. They represent more than $20 \%$ of the total genes and let us to suppose that addition of nitrate and nitrite to meat leads to a global change in gene expression. This profile revealed that $S$. xylosus is subject to nitrosative stress caused by reactive nitrogen species (RNS) generated from nitrate and nitrite. To overcome this stress, S. xylosus has developed several oxidative stress resistance mechanisms, such as modulation of the expression of several genes involved in iron homeostasis and in antioxidant defense. Most of which belong to the Fur and PerR regulons, respectively. S. xylosus has also counteracted this stress by developing DNA and protein repair. Furthermore, it has adapted its metabolic response-carbon and nitrogen metabolism, energy production and cell wall biogenesis-to the alterations produced by nitrosative stress.

Keywords: Staphylococcus xylosus, starter, nitrate, nitrite, transcriptome, nitrosative stress, meat

\section{INTRODUCTION}

Staphylococci are commensals of the skin and mucous membranes of animals and are found in various niches (Kloos et al., 1976; Nagase et al., 2002). Products of animal origin are naturally contaminated by staphylococci. Staphylococcus xylosus is one of the three species frequently isolated from cheeses and dry fermented sausages (Coton et al., 2010). Furthermore, S. xylosus is commonly used as starter culture in meat fermentation (Talon and Leroy, 2011). This bacterium contributes to the development of flavor through its antioxidant properties and degradation of amino acids (Barrière et al., 2001a,b, 2002; Talon et al., 2002). But its main function in cured products is to reduce nitrate to nitrite which is necessary for the development of color and flavor. In fermented meat products, nitrite is then reduced by chemical reactions to nitric oxide $(\mathrm{NO})$, which interacts with myoglobin to form nitrosomyoglobin, which gives the meat a stable red color (Gøtterup et al., 2007). Nitrite is responsible for the production of the characteristic flavor of cured meat through complex mechanisms not entirely understood. Furthermore, nitrite and derived compounds act in meat as an antioxidant preventing lipid oxidation and therefore the development of rancid offflavors (Cammack et al., 1999). Besides its role in color and flavor formation, nitrite preserves meat products against growth of undesirable anaerobic bacteria and some pathogenic bacteria (Tompkin, 1995).

The reduction of nitrate and nitrite is well described in laboratory media for Staphylococcus carnosus, another meat starter culture (Neubauer and Götz, 1996). Compared with S. carnosus, the nitrate reductase activity of $S$. xylosus is poorly characterized and the nitrite reductase has not been described. Most strains of S. xylosus, like other meat-associated staphylococci, have a nitrate reductase activity (García-Varona et al., 2000; Mauriello et al., 2004).

Cured meat products have been manufactured using nitrate and nitrite since ancient times. In most countries, the use of nitrate and nitrite, usually added as potassium or sodium salts, is controlled in cured meat. Added or residual amounts are regulated by laws. A European parliament and council directive (directive 2006/52/EC) established limits of $150 \mathrm{mg}$ nitrite/ $\mathrm{kg}$ and $300 \mathrm{mg}$ nitrate $/ \mathrm{kg}$ for non-heated meat products. The limits on residual amounts are $50 \mathrm{mg}$ nitrite $/ \mathrm{kg}$ and $250 \mathrm{mg}$ nitrate $/ \mathrm{kg}$ in dried meat products (Honikel, 2008). Nitrate (after its conversion to nitrite) and nitrite have various valuable properties, but their safety is still questioned because of their contribution to the formation of carcinogenic nitrosamines. The current aim is to further restrict the use of nitrate and nitrite in meat products. 
Functional starter cultures may be useful to reduce the levels of nitrate and nitrite as suggested by Leroy et al. (2006). However, the impact of these curing agents on the physiology of the starter cultures in meat is still unknown.

In this study, we characterized the transcriptomic effects of nitrate and nitrite at the levels used in the meat industry on the physiology of $S$. xylosus directly in a meat model, thereby establishing for the first time the in situ response to these additives. The transcriptome was analyzed in meat incubated in conditions that mimic the fermentation step in sausage manufacturing. The nitrosative stress generated by addition of nitrate and nitrite may trigger defense mechanisms developed by $S$. xylosus. One concerns modulation of the expression of several genes involved in iron homeostasis and the other concerns genes involved in antioxidant defense. Furthermore, this stress modifies the expression of several genes involved in carbon and nitrogen metabolism, energy production, cell wall biogenesis, and DNA and protein repair.

\section{MATERIALS AND METHODS BACTERIAL STRAIN AND CULTURE CONDITIONS}

The S. xylosus C2a strain is derived from the type strain DSM20267 cured of its endogenous plasmid pSX267. We used this laboratory strain as it is the only one with some genetic background. Moreover, its complete genome has been sequenced (LN554884). The strain was cultured overnight at $30^{\circ} \mathrm{C}$ in a minimal medium (Fiegler and Brückner, 1997). The culture was centrifuged and the cell pellet was resuspended in physiological serum and used to inoculate the meat model with $10^{7} \mathrm{CFU} / \mathrm{g}$ of meat. To evaluate the inoculum and growth of $S$. xylosus in meat, bacteria were enumerated after serial dilutions on plates of brainheart infusion agar (Difco Laboratories, Detroit, $\mathrm{MI}$ ), which were incubated at $30^{\circ} \mathrm{C}$ for $24 \mathrm{~h}$.

\section{MEAT MODEL}

Frozen vacuum-packed ground pork meat sterilized by irradiation $(15 \mathrm{kGy})$ was used. After thawing the meat at $4^{\circ} \mathrm{C}$, two batches were prepared. One batch with nitrate and nitrite was prepared as follows per $\mathrm{kg}$ of meat: $5 \mathrm{~g}$ of glucose, $27.7 \mathrm{~g}$ of $\mathrm{NaCl}$, $0.18 \mathrm{~g}$ of $\mathrm{KNO}_{3}, 0.03 \mathrm{~g}$ of $\mathrm{NaNO}_{2}$. The second batch was prepared as before but without nitrate and nitrite. After inoculation with $S$. xylosus, each batch was distributed in glass Petri dishes and incubated at $22^{\circ} \mathrm{C}$ in a wet atmosphere for up to $72 \mathrm{~h}$. Three independent experiments were done.

\section{ANALYTICAL METHODS}

The samples were analyzed at 6 times of incubation $(0,2,8,24,48$, and $72 \mathrm{~h}$ ): measurement of meat $\mathrm{pH}$ ( $\mathrm{pH}$ meter MP230, Mettler Toledo/ sonde Inlab 413,Viroflay, France), evaluation of nitrate and nitrite concentrations in meat by reducing nitrate to nitrite with metallic cadmium and by addition of sulphanilamide chloride and $\mathrm{N}$-(1-naphthyl)-ethylene-diamine dihydrochloride plus measurement of absorbance at $538 \mathrm{~nm}$ (NF V04-410), and visual evaluation of meat surface color.

\section{TOTAL RNA EXTRACTION}

At 24 and $72 \mathrm{~h}$ of incubation, several aliquots of $200 \mathrm{mg}$ meat samples were taken from each batch of the three independent experiments and immediately frozen in liquid nitrogen to stabilize the bacterial RNA. For RNA extraction, $1.25 \mathrm{~mL}$ of Trizol reagent (Invitrogen, Cergy Pontoise, France) was added to the meat sample. The samples were transferred to tubes containing $800 \mathrm{mg}$ of zirconia-silica beads $(0.1 \mathrm{~mm}$ diameter $)$ used to break the bacterial cells and were vigourously shaken in a bead beater (FastPrep, MP Biomedicals, Illkirch-Graffenstaden, France), after which $280 \mu \mathrm{L}$ of chloroform was added. After centrifugation, the upper phase containing RNA was collected and a mixture of acid phenol/chloroform/isoamyl alcohol (25/24/1) was added. After centrifugation, the upper phase was purified with the Nucleospin RNA II kit (Macherey Nagel, Hoerdt, France) according to the manufacturer's instructions. A supplementary treatment was performed with Turbo DNAse (Ambion, Austin, TX) to remove all traces of contaminating DNA. The absence of $S$. xylosus genomic DNA contamination was verified by PCR targeting the $r p o B$ gene. Total RNA isolated was quantified using a Nanodrop 1000 (Thermo Fisher Scientific, Wilmington, DE) and RNA quality was analyzed using an Agilent 2100 Bioanalyzer (Agilent Technologies, Santa Clara, CA) according to the manufacturer's instructions. The RNA was stored at $-80^{\circ} \mathrm{C}$.

\section{RNA LABELING AND MICROARRAY}

We have developed a DNA microarray specific to S. xylosus C2a based on an Agilent technology microarray. This array has 19,805 probes targeting the whole $S$. xylosus C2a genome. On average there are 6-10 probes per gene. A complete description of the array is available at the NCBI Gene Expression Omnibus (GEO) database under platform accession number GPL19201.

RNA from each sample was reverse transcribed to cDNA with SuperScript Reverse Transcriptase according to the manufacturer's instructions (Invitrogen). The RNA-cDNA hybrids were then digested using RNAse $\mathrm{H}$ (Invitrogen). The cDNA was labeled with Cy3 dCTP or Cy5 dCTP using the Bioprime DNA kit according to the manufacturer's instructions (Invitrogen). Unincorporated Cy-dye was removed using a CentriSep column (Applied Biosystems, Warrington, United Kingdom) and dye swap experiments were performed. Cy3/cDNA and Cy5/cDNA were mixed with Agilent hybridization buffer and hybridized at a temperature of $60^{\circ} \mathrm{C}$ for $17 \mathrm{~h}$ in a dedicated hybridization oven. After washing and drying, microarrays were scanned in a SYSSN-ARRAY Agilent Microarray Scanner (5- $\mu \mathrm{m}$ resolution) with a coefficient of photomultiplication of $30 \%$.

\section{MICROARRAY DATA ANALYSIS AND STATISTICAL TREATMENT}

Microarrays were analyzed by the Feature extraction software (Agilent, version 9.1.3.1) in 3 steps: localization of the spots, segmentation of the pixels and extraction of qualitative and quantitative data. These data were filtered to remove spots that were saturated or of poor quality. Within each array, Cy3/Cy5 log-ratios were normalized to correct for the mean spot intensitydependent dye effect. Significant differences in the probe set intensities between the two conditions were identified using a linear model with an empirical Bayes method using all information probes to moderate the standard errors of the estimated logfold changes (Smith, 2004). The probabilities were corrected by the Benjamini-Hochberg procedure in order to control the 
false-discovery rate (FDR) with a $p$-value cut-off of 0.05 . All the probes with an FDR $\leq 0.05$ are considered to be differentially expressed. Finally, one gene was considered to be differentially expressed if at least $66 \%$ of the corresponding probes were differentially expressed.

\section{QUANTITATIVE PCR (qPCR)}

qPCR was used to validate the microarray analysis and was performed using Real Plex Master Cycler (Eppendorf, Hamburg, Germany) with $\mathrm{IQ}^{\mathrm{TM}}$ SYBR ${ }^{\circledR}$ Green Supermix (Bio-Rad, Hercules, CA). Thermal cycling consisted of $30 \mathrm{~s}$ at $95^{\circ} \mathrm{C}$, followed by 40 cycles of $15 \mathrm{~s}$ at $95^{\circ} \mathrm{C}$ and $60 \mathrm{~s}$ at $60^{\circ} \mathrm{C}$. The targeted genes and primer sequences are listed in Supplementary Table 1. All genes were quantified in duplicate for the three independent experiments. The analyses were performed on the same batches of RNA as those used for the microarray experiments. The housekeeping gene $r p o B$ was used as reference gene for normalization. Results were calculated using the comparative cycle threshold method (Pfaffl, 2001).

\section{MICROARRAY DATA ACCESSION NUMBER}

The microarray samples and data have been deposited in the GEO database under accession number GSE61514.

\section{RESULTS AND DISCUSSION \\ BEHAVIOR OF $S$. XYLOSUS IN THE MEAT MODEL}

Bacterial growth was similar in the two batches of meat with or without nitrate and nitrite in the three independent replicates. Inoculated at $5 \times 10^{7} \mathrm{CFU} / \mathrm{g}$, the growth of $S$. xylosus was exponential until $\mathrm{t}_{24 \mathrm{~h}}$ when the population reached $9 \times 10^{8}$ $\mathrm{CFU} / \mathrm{g}$. It remained in the stationary phase until the end of the experiment (Supplementary Figure 1). These results differ from those of Neubauer and Götz (1996) showing that nitrate and nitrite promote the growth of $S$. carnosus. However, Neubauer and Götz's experimental conditions differed greatly from ours: in vitro in laboratory media vs. in situ in our meat model, and nitrate $(25 \mathrm{mM})$ and nitrite $(2 \mathrm{mM})$ concentrations that were very high compared with the $0.18 \mathrm{mM}$ and $0.09 \mathrm{mM}$, respectively, we used.

The $\mathrm{pH}$ was measured at each point between $\mathrm{t}_{0 \mathrm{~h}}$ and $\mathrm{t}_{72 \mathrm{~h}}$. As expected, only a weak acidification was observed in the meat model. The $\mathrm{pH}$ values were near 5.9 at $\mathrm{t}_{0 \mathrm{~h}}$ and near 5.7 at $\mathrm{t}_{72 \mathrm{~h}}$. Addition of nitrate and nitrite had no effect on acidification in the meat. In our experiments, $\mathrm{pH}$ was less acid than in fermentation carried out in the presence of lactic acid bacteria, in which the $\mathrm{pH}$ can range from 4.5 to 5.3 (Demeyer et al., 2000).

Nitrate and nitrite were not detected in the batch prepared without nitrate and nitrite, whereas the initial concentrations of nitrate $(180 \mathrm{mg} / \mathrm{kg}$ of meat) and nitrite $(30 \mathrm{mg} / \mathrm{kg}$ of meat) added to the meat model were found at $t_{0 \mathrm{~h}}$. Nitrate concentration decreased to $31 \mathrm{mg} / \mathrm{kg}$ of meat until $\mathrm{t}_{24 \mathrm{~h}}$ and remained at $25 \mathrm{mg} / \mathrm{kg}$ until $\mathrm{t}_{72} \mathrm{~h}$. Concomitantly, the nitrite concentration rose to $133 \mathrm{mg} / \mathrm{kg}$ of meat at $\mathrm{t}_{24 \mathrm{~h}}$ and then decreased slowly to $92 \mathrm{mg} / \mathrm{kg}$ of meat at $\mathrm{t}_{72 \mathrm{~h}}$.

In parallel, a sharp color difference was observed between the two batches. In the presence of nitrate and nitrite at $t_{72 h}$, the meat was red because of the formation of nitrosylmyoglobin (MbFeIINO), while the meat in the other batch was brown due to the production of metmyoglobin (data not shown). In meat, the nitrite undergoes chemical reactions that lead to reactive nitrogen species (RNS), including NO (Honikel, 2008; Hammes, 2012). These RNS as well as reactive oxygen species (ROS) can interact with and damage numerous targets, including thiols, metal centers, tyrosine residues, nucleotide bases and lipids (Gaupp et al., 2012).

\section{TRANSCRIPTOMIC ANALYSIS AND VALIDATION}

A total of 627 genes were differentially expressed at $t_{24 h}$ and $t_{72 h}$ in the presence of nitrate and nitrite in situ in meat. This represented close to $24 \%$ of the 2634 total predicted genes in strain C2a. There were 466 genes at $\mathrm{t}_{24 \mathrm{~h}}$ with $222 \mathrm{up}$ - and 244 down-regulated and 241 genes at $t_{72} \mathrm{~h}$ with 112 up- and 129 down-regulated. Only 80 common genes were differentially expressed at the two times of incubation. All the genes that passed our selection criteria are listed in Supplementary Table 2.

To validate the microarray analysis independently, the relative expression of 38 differentially expressed genes representing $6 \%$ of genes with significantly modified expression was measured by qPCR. The microarray and qPCR results for the tested genes were strongly correlated at $24 \mathrm{~h}\left(r^{2}=0.806\right.$; slope $\left.=1.061\right)$ and $72 \mathrm{~h}\left(r^{2}=0.848\right.$; slope $\left.=0.886\right)$ and the expected trend in the expression pattern was confirmed (Figure 1).

\section{COG DISTRIBUTION IN THE TRANSCRIPTOME}

The COG distribution of genes up- or down-regulated in response to RNS generated from nitrate and nitrite is shown in Figure 2. The most represented groups are genes involved in information storage and processing, cellular processes and metabolism. Many of the differentially regulated genes are unclassified or belong to the category "function unknown" [S] or "general function prediction only" [R]. At $t_{24}$, for the up-regulated genes, the most-well represented categories were transcription $[\mathrm{K}]$, post-translational modification, protein turnover, and chaperones [O], amino acid transport and metabolism [E], carbohydrate transport and metabolism [G], inorganic ion transport and metabolism $[\mathrm{P}]$. For the down-regulated genes, the 4 dominant categories were cell wall/membrane/envelope biogenesis $[\mathrm{M}]$, energy production and conversion [C], amino acid transport and metabolism [E] and translation, ribosomal structure, and biogenesis [J]. We observed a similar distribution for up- and down-regulated genes at $\mathrm{t}_{72 \mathrm{~h}}$.

\section{EXPRESSION OF nar AND nir GENES}

As in fermented meat products, in our experiment nitrate was reduced to nitrite by $S$. xylosus. The organization of nar and nir loci in the S. xylosus C2a genome is the same as in S. carnosus. No differential expression of nar and nir genes was noted between the two batches, i.e., with or without nitrate and nitrite at $t_{24 h}$ and $t_{72 h}$. This is not surprising, at least for nar expression, as the reduction of nitrate to nitrite was mostly achieved at $t_{24 h}$, as revealed by the assays of nitrate and nitrite during the incubation. Furthermore, the nitrate reductase activity of S. xylosus peaked during exponential growth in laboratory media supplemented 


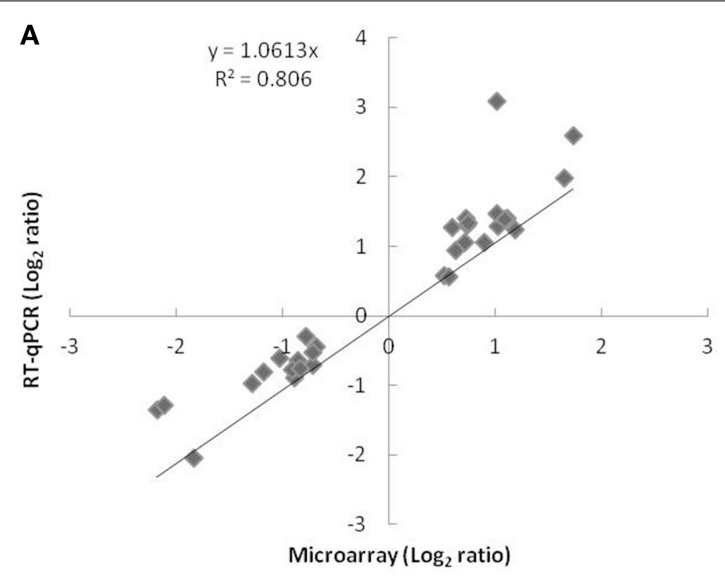

FIGURE 1 | Comparison of log2 expression ratios of 38 differentially regulated genes measured by using microarray and qPCR at $\mathbf{t}_{\mathbf{2 4 h}}$ (A) or $\mathbf{t}_{\mathbf{7 2 h}}$ (B). Positive and negative log2 expression ratios

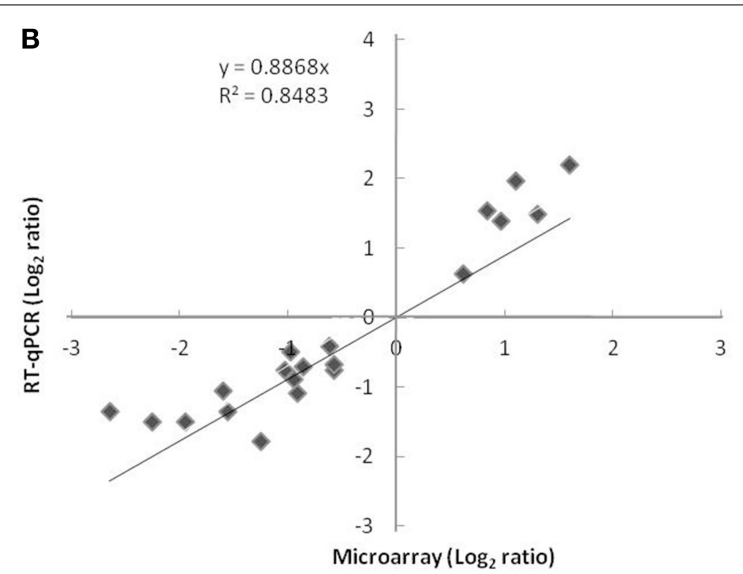

represent up- and down-regulation in the presence of nitrate and nitrite. Each data point is calculated from averages of biological triplicates.

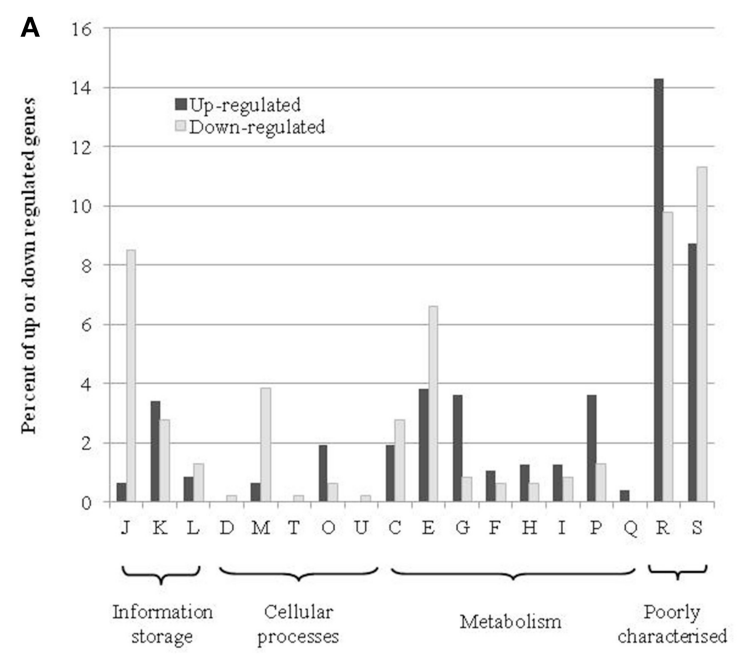

FIGURE 2 | COG distribution of differentially up-and down-regulated genes in the transcriptome at $\mathbf{t}_{\mathbf{2 4 h}}(\mathrm{A})$ or $\mathbf{t}_{\mathbf{7 2 h}}(\mathrm{B})$. The percentages represent the number of genes that are in a category relative to the respective total number of genes that were up- or down-regulated. The COG abbreviations are as follows: [J] translation, ribosomal structure, and biogenesis; [K] transcription; [L] replication, recombination, and repair; [D] cell cycle control, cell division, and chromosome partitioning; [M] cell

wall/membrane/envelope biogenesis; [T] signal transduction mechanisms; [O]

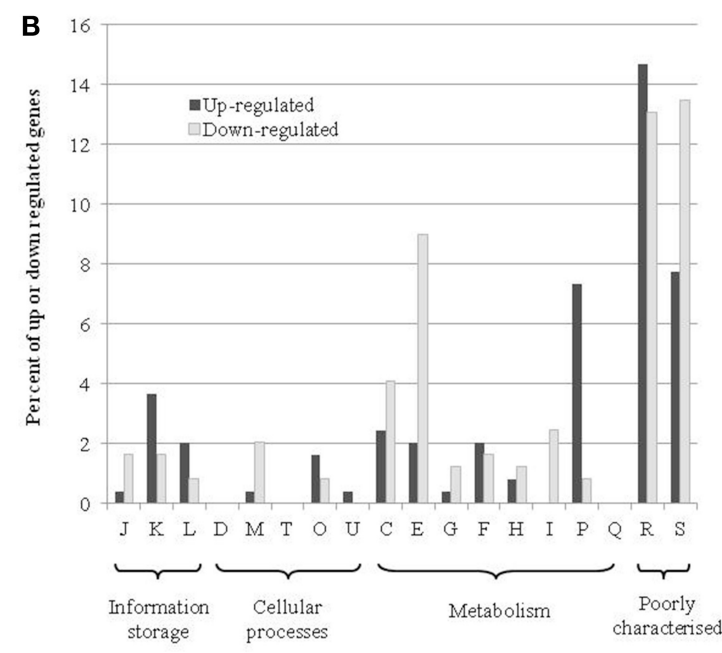

post-translational modification, protein turnover, and chaperones; [U] intracellular trafficking, secretion, and vesicular transport; [C] energy production and conversion; [E] amino acid transport and metabolism; [G] carbohydrate transport and metabolism; [F] nucleotide transport and metabolism; [H] coenzyme transport and metabolism; [l] lipid transport and metabolism; [P] inorganic ion transport and metabolism; [Q] secondary metabolite biosynthesis, transport, and catabolism; [R] general function prediction only; [S] function unknown. with nitrate (Talon et al., 1999). The nitrite can modulate the transcription of the nir operon during anaerobic and aerobic growth of S. carnosus (Neubauer et al., 1999). But in this in vitro study, $2 \mathrm{mM}$ nitrite was used to enhance the transcriptional level. In our conditions, the maximum concentration of nitrite measured was $0.4 \mathrm{mM}$. In S. carnosus, the transcription of the nar and nir operons is under the control of NreBC, which regulates anaerobic respiration (Fedtke et al., 2002). In our meat model, with or without nitrate and nitrite, $S$. xylosus is subject to the same oxygen conditions, which could explain the non-differential expression of nar and nir genes.

\section{IRON HOMEOSTASIS AND THE FUR REGULON}

In meat, $S$. xylosus responded to the presence of RNS by the up-regulation of 17 genes involved in iron acquisition (Table 1). Most of these genes were related to the production or harnessing of siderophores ( $s f a, h t s, f h u, s s t)$. Two siderophores may be produced by staphylococci: staphyloferrin A (SA) and staphyloferrin B (SB) (Beasley and Heinrichs, 2010; Sheldon and Heinrichs, 2012; Saha et al., 2013). In our study, only the genes $s f a A B C D$ with genetic organization similar to that of Staphylococcus aureus encoding enzymes for the synthesis of SA were identified (Hammer and Skaar, 2011). Adjacent to this 
Table 1 | Genes of Staphylococcus xylosus discussed in this study differentially expressed over time in meat in the presence of nitrate and nitrite.

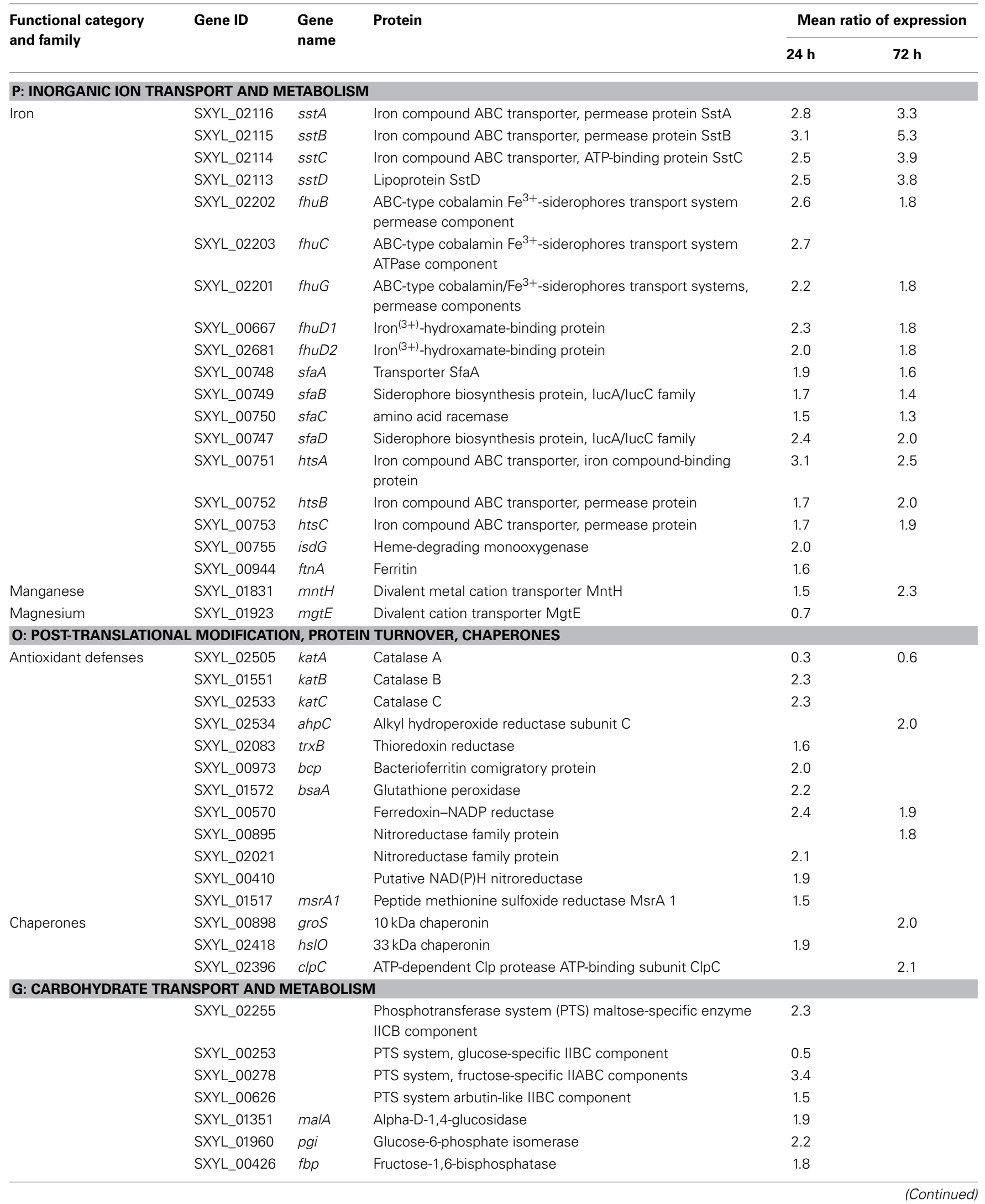


Table 1 | Continued

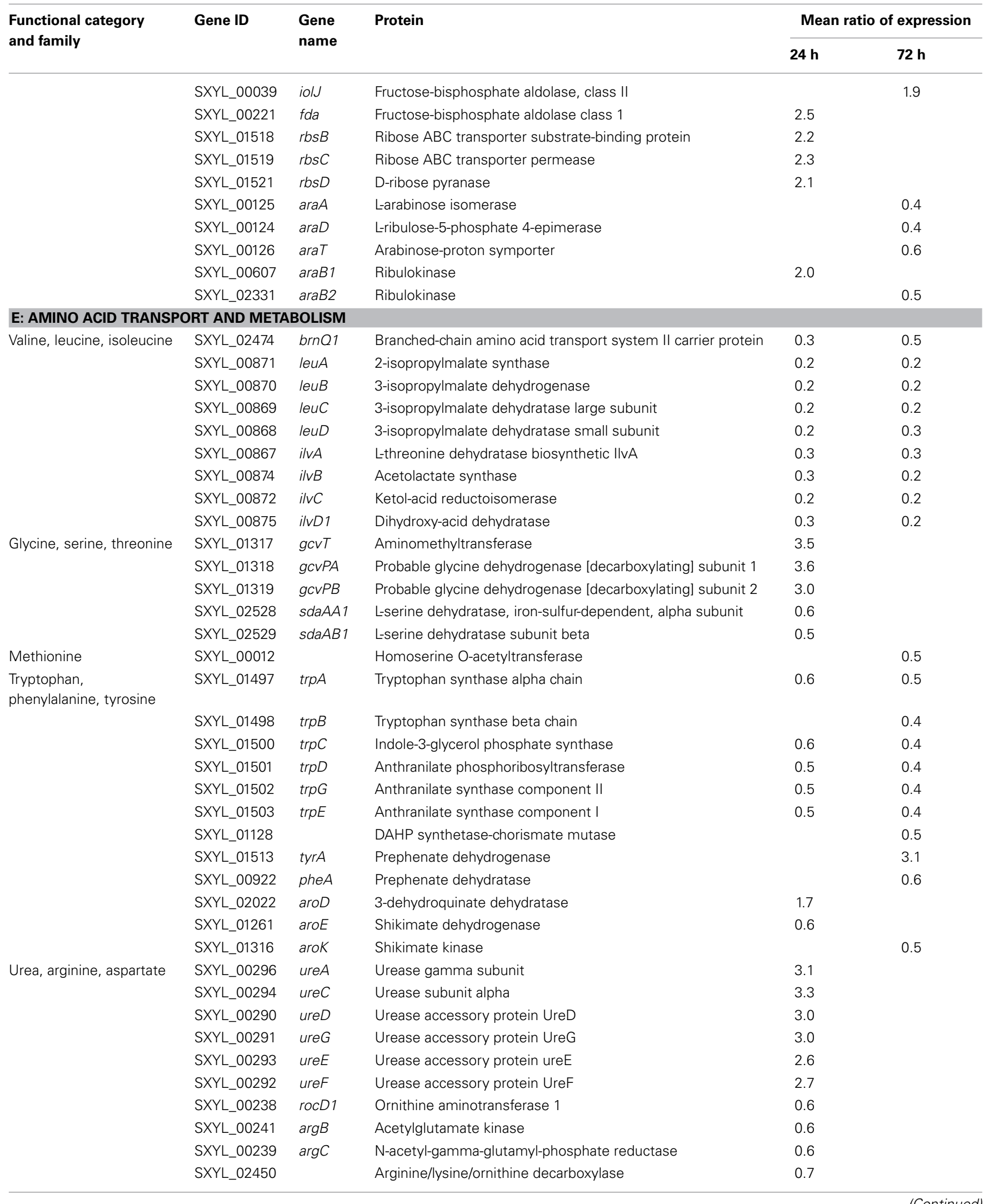

(Continued) 
Table 1 | Continued

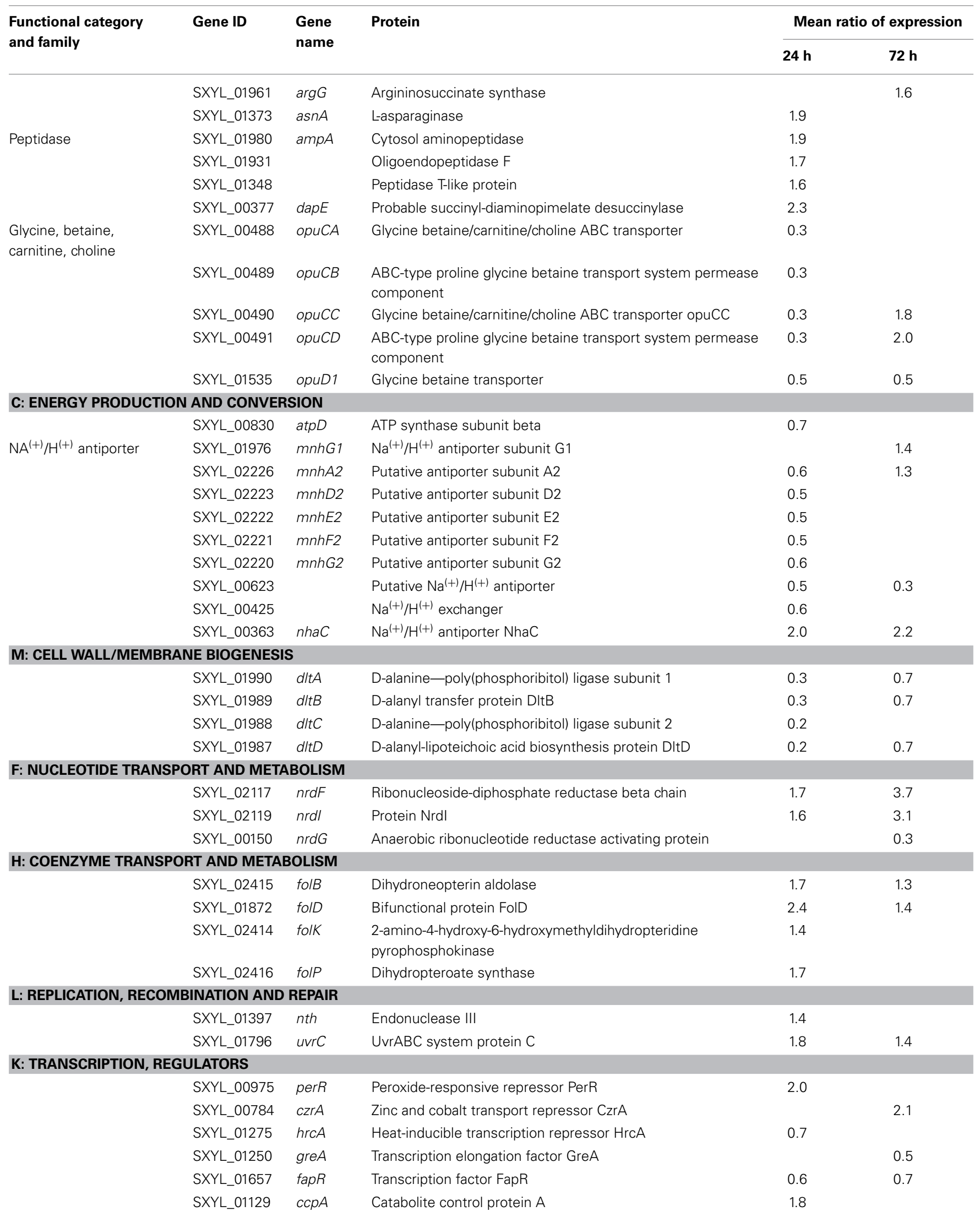


locus, also as described in $S$. aureus, a cluster of 3 genes $h t s A B C$ encodes the ABC transporter for uptake of Fe-SA. The hts-sfa locus is found in all staphylococcal genomes, while the locus encoding SB is only found in S. aureus and Staphylococcus pseudointermedius (Sheldon and Heinrichs, 2012). In parallel, we confirmed by a chrome azurol S assay that the S. xylosus strain C2a incubated in Staphylococcal Siderophore Detection medium (Schwyn and Neilands, 1987) produced siderophores (data not shown). Staphylococci have not been shown to synthesize hydroxamate and catechol siderophores, but they are known to be able to utilize them as iron sources (Sheldon and Heinrichs, 2012). S. xylosus possesses both the Fhu system involved in the uptake of hydroxamate- and the Sst system for the catechol-type siderophores. As for $S$. aureus, a cluster of three genes fhuCBG encodes a dimeric permease (FhuBG) and an ATPase (FhuC) and two separate genes $(f h u D 1, f h u D 2)$ encode substrate-binding lipoproteins. FhuC serves also as an ATPase for the import of Fe-SA (Sheldon and Heinrichs, 2012). Finally, a cluster of four genes sst $A B C D$ encodes an $\mathrm{ABC}$ transporter and SstD, which binds ferrated catechol siderophores and catecholamines, but also a broader range of potential substrates. This locus is highly conserved in $S$. aureus strains and is present in most coagulasenegative staphylococci (Sheldon and Heinrichs, 2012). The single gene is $G$ encoding a cytoplasmic heme-degrading monooxygenase was up-regulated in S. xylosus in the presence of RNS. In S. aureus, this gene belongs to the operon isdCDEFsrtBisdG which, together with four other operons, encodes the Isd system involved in heme-mediated iron acquisition (Hammer and Skaar, 2011). Unlike S. aureus, S. xylosus does not possess the other genes of the Isd system. Heme is used as a cofactor in many biological systems due to the redox potential of the iron atom, but at high levels this molecule can be toxic. IsdG could be used to regulate endogenous heme synthesis and metabolism (Haley and Skaar, 2012). Degradation of heme by IsdG releases iron, carbon monoxide and oxo-bilirubin, which has potent antioxidant properties (Haley and Skaar, 2012). IsdG has been found in many classes of bacteria, which underlines the importance of heme degradation. Despite the role of heme as cofactor and as iron and bilirubin sources, heme homeostasis is not yet understood (Haley and Skaar, 2012).

Concomitant with up-regulation of genes involved in iron acquisition, a gene involved in iron storage, fntA which encodes ferritin, was up-regulated in $S$. xylosus in the presence of RNS (Table 1). Ferritins are ubiquitous iron-storage proteins which can also protect against metal toxicity and oxidative stress (Andrews, 1998). They have been well-characterized in S. aureus and Staphylococcus epidermidis (Horsburgh et al., 2001a; Morrissey et al., 2004).

Iron is an essential nutrient, but as high levels of free intracellular ferric iron are toxic to cells, the amount of free iron has to be strictly regulated. In many bacteria, the ferric uptake regulator (Fur) functions as a transcriptional repressor for iron homeostasis. When complexed with iron, Fur regulates the transcription of genes by binding a consensus sequence known as the Fur box within the promoter region (Morrissey et al., 2004; Sheldon and Heinrichs, 2012). Genes involved in iron acquisition are repressed by Fur and thus Fur boxes controlling the expression of these genes in $S$. aureus have been described (Sheldon and Heinrichs,
2012). We have looked for Fur boxes in S. xylosus genes coding for iron acquisition by using the inverted repeat sequence of 19-bp described for $S$. aureus. We found putative sequences located close to a $35 \mathrm{bp}$ site within the promoter region for $h t s A, s s t A, f h u C$, $f h u D 1, f h u D 2$ with nucleotide identity to the $S$. aureus Fur box consensus sequence (Figure 3). Fur protein functions as a repressor. Under iron-replete conditions, $\mathrm{Fe}^{2+}$ binds to Fur and the Fur-Fe ${ }^{2+}$ homodimer binds to the Fur box sequence and inhibits the transcription (Hassan and Troxell, 2013). With iron deprivation, there is an increase in the transcription of genes involved in iron uptake. In meat, a lot of iron sources are available: ferritin, myoglobin, transferrin, and hemoglobin, which raises the question of why $S$. xylosus senses an iron deficiency environment in the presence of RNS. Fur can sense not only iron but also an oxidative environment (Fillat, 2014). It has been demonstrated that $\mathrm{NO}$ and peroxide can modulate Fur activity (Spiro, 2007). The direct interaction of NO with iron center of Fur leads to the inhibition of Fur activity resulting in the induction of iron-regulated genes by NO in E. coli (D'Autréaux et al., 2002; Mukhopadhyay et al., 2004). NO can react with iron in Fur-Fe and abolish DNA binding and thus induce genes repressed by Fe-Fur in S. aureus (Richardson et al., 2006). Thus, we hypothesized that NO from nitrite can inactivate Fur, thus derepressing the regulon, and consequently genes involved in iron intake are up-regulated in S. xylosus (Figure 4).

\section{ANTIOXIDANT DEFENSES AND THE PerR REGULON}

The nitrosative stress can be augmented by intracellular iron, which can react with $\mathrm{H}_{2} \mathrm{O}_{2}$ by Fenton chemistry giving rise to damaging hydroxyl radicals (HO'). S. xylosus responded to this stress by the regulation of 12 genes involved in protection

\begin{tabular}{|c|c|}
\hline $\mathbf{A}_{\text {Fur box }}$ & GATAATGATAATCATTATC \\
\hline$h \operatorname{tsA}$ & GACACCGATAATCATTATC \\
\hline sstA & GATAATGATTATCATAACC \\
\hline fhuc & GATAATGATTATCATTTAC \\
\hline fhuD2 & GATAATCATTATCAATAGG \\
\hline fhuD1 & GATAATCATTTTCATTGGA \\
\hline & 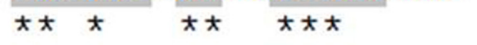 \\
\hline \multicolumn{2}{|r|}{40} \\
\hline Per box & АТТАТ-ААТТАТТАТААТ- \\
\hline perR & GTTAT--ATTAATATTAAG \\
\hline fur & ATTAT-AATTATTAGTAG- \\
\hline ahpc & АTTAG-AАTTATTATAAT- \\
\hline katB & GTAAT-AАTTATTATTAT- \\
\hline katc & AGAAT-AATTAT-GCTTCG \\
\hline $\operatorname{trx} B$ & -TAATGAATTATTAA-ATA \\
\hline$f \operatorname{tn} A$ & АСTAT-GATTATTGTGTA- \\
\hline SXYL_00895 & $\frac{\text { GATAT-AATTATTATACT- }}{\star} \frac{-}{\star \star \star \star}$ \\
\hline \multicolumn{2}{|c|}{$\begin{array}{l}\text { FIGURE } 3 \text { | Alignment of the putative Fur boxes (A) and PerR boxes (B) } \\
\text { identified in the Staphylococcus xylosus C2a genes coding for iron } \\
\text { homeostasis and antioxidant properties. }{ }^{*} \text { Conserved position. }\end{array}$} \\
\hline
\end{tabular}




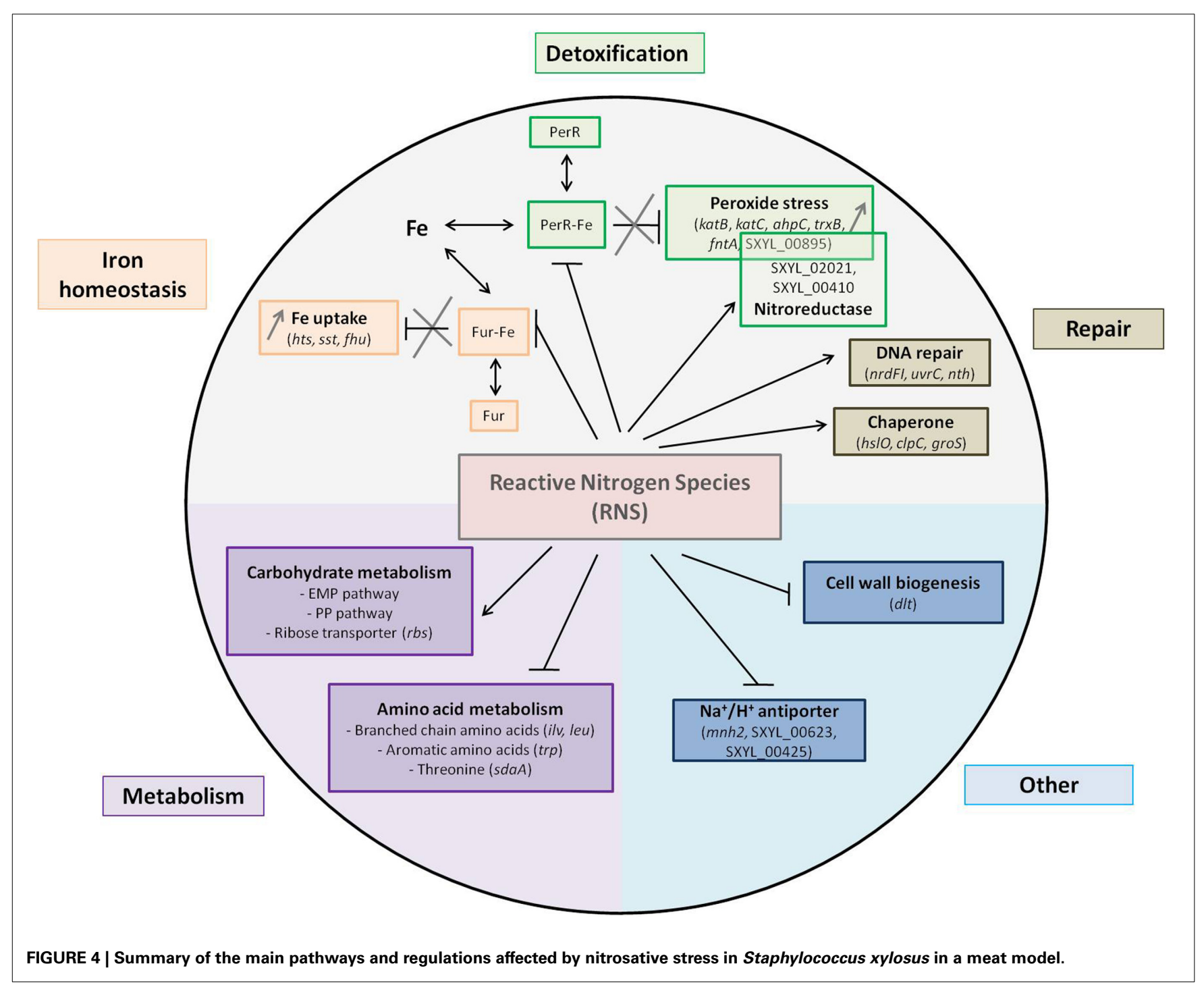

and detoxification mechanisms (Table 1, Figure 4). Among these genes, three encode catalases with kat $A$ down-regulated and $k a t B$ and $k a t C$ up-regulated. Most staphylococci are catalase-positive with the majority, like S. aureus, having a single catalase (Gaupp et al., 2012). S. carnosus has two catalases (Rosenstein et al., 2009). Some strains of S. xylosus, Staphylococcus saprophyticus and Staphylococcus equorum have been reported to have two catalases (Blaiotta et al., 2010). The S. xylosus strain C2a has three catalases. The transcription of katA in this strain is induced upon entry into the stationary phase, by oxygen and by hydrogen peroxide, whereas iron and manganese have a repressive effect (Barrière et al., 2002). KatB and KatC were identified in the cell envelope of this strain with KatC exhibiting similarity with KatE of Bacillus subtilis (Planchon et al., 2009). In addition, gene ahpC encoding alkyl hydroperoxide reductase, $\operatorname{tr} x B$ encoding thioredoxin reductase and $b c p$ for bacterioferritin comigratory protein were all up-regulated. In S. aureus, catalase detoxifies $\mathrm{H}_{2} \mathrm{O}_{2}$ while AhpC confers resistance to other ROS (Gaupp et al., 2012). After NO stress, KatA and AhpF were overexpressed in B. subtilis but not in S. aureus (Hochgräfe et al., 2008). Bacterioferritin comigratory protein (Bcp) functions as an iron chelator and is homologous to a thioreductase-peroxidase and as such is likely involved in the thiol-dependent reduction of peroxides (Gaupp et al., 2012). As described for other bacteria, the thioredoxin system of $S$. xylosus comprises thioredoxin $(\operatorname{tr} x A)$ and thioredoxin reductase $(\operatorname{tr} x B)$. Transcription of these two genes is increased in response to diamide, $\mathrm{H}_{2} \mathrm{O}_{2}$, heat, salt or ethanol stress in B. subtilis and in S. aureus (Gaupp et al., 2012). Thioredoxins are major contributors to oxidative resistance by facilitating the reduction of $\mathrm{H}_{2} \mathrm{O}_{2}$, and by scavenging $\mathrm{HO}^{\prime}$ (Gaupp et al., 2012). They help maintain protein thiols in their reduced form and thus the reduced state of the cytoplasm. Moreover, to respond to the nitrosative stress, the gene $b s a A$ encoding glutathione peroxidase, which catalyzes the reduction of $\mathrm{H}_{2} \mathrm{O}_{2}$, and the gene SXYL_00570, which encodes ferredoxin-NADP reductase, were up-regulated in S. xylosus. In parallel to the up-regulation of $\operatorname{tr} x B$, the gene msrAl encoding a peptide methionine sulfoxide reductase (Msr) was up-regulated in S. xylosus in the presence of RNS 
(Table 1). Msr catalyzes the reduction of free and bound methionine sulfoxide [Met-(S)-SO; Met-(R)-SO] (Moskovitz, 2005). The catalytic process, with thioredoxin as reducing agent, includes the production of a sulfenic intermediate with concomitant release of the repaired methionine and then a recycling step where oxidized Msr is reduced to its active form (Ezraty et al., 2005). The oxidized $\mathrm{S}$ form of methionine is reduced by the enzyme MrsA while the $\mathrm{R}$ form is reduced by MsrB. S. aureus contains three paralogs of $m s r A$ ( $m s r A 1, m s r A 2, m s r A 3)$ and a single $m s r B$ gene (Singh and Moskovitz, 2003; Ezraty et al., 2005). Similarly, S xylosus contains three $m s r A$ genes and one $m s r B$. In $S$. aureus, MsrAl is the major contributor to tolerance of oxidative stress (Singh and Moskovitz, 2003).

Furthermore, two genes (SXYL_00895; SXYL_02021) encoding two probable nitroreductases and one gene (SXYL_00410) encoding a putative $\mathrm{NAD}(\mathrm{P}) \mathrm{H}$ nitroreductase were overexpressed in S. xylosus grown in the presence of RNS (Table 1, Figure 4). Nitroreductases have been classified into three classes: class A represented by E. coli NfsA and including S. aureus NfrA, class B represented by $E$. coli $\mathrm{NfsB}$ and class $\mathrm{C}$ including $S$. aureus NtrA (Tavares et al., 2009). The S. aureus NfrA is a flavin mononucleotide-dependent NADP oxidase involved in the oxidative stress response (Streker et al., 2005). In addition, this protein showed nitroreductase activity and weak disulfide reductase activity. The transcription of $n r f A$ was strongly induced by nitrofurantoin, thiol-specific oxidant diamide and high concentrations of hydrogen peroxide, and a PerR box was identified (Streker et al., 2005). A putative PerR-binding site upstream of SXYL_00895 has been identified (Figure 3). As for S. aureus, this nitroreductase may play a role in the nitrosative stress response and help to maintain the thiol-disulfide balance. Moreover, SXYL_02021 shows a high degree of similarity with $\mathrm{NtrA}$. NtrA has an S-nitrosoglutathione reductase activity involved in nitrosative metabolism (Tavares et al., 2009). Our results led us to suppose that in S. xylosus three nitroreductases could be involved in the response to nitrosative stress.

The gene per encoding the transcriptional regulator PerR, which belongs to the Fur family, was up-regulated in the presence of RNS in S. xylosus (Table 1). As a member of the Fur family, the activity of PerR is dependent on metal ions (Horsburgh et al., 2001b). In B. subtilis, PerR carries structural zinc and its DNAbinding activity is enhanced by Fe (II) or Mn (II) (Gaupp et al., 2012). PerR, containing Fe or Mn, functions as a transcriptional repressor by binding to a consensus DNA sequence called the PerR Box (Horsburgh et al., 2001a; Gaupp et al., 2012). S. aureus PerR regulates genes for antiperoxidative enzymes and iron storage proteins and represses the fur gene, which controls iron homeostasis. We looked for the PerR box in S. xylosus genes involved in iron acquisition and storage and antioxidant properties by using the consensus sequence of 17-bp described for $S$. aureus (Horsburgh et al., 2001a,b). We found a putative PerR-binding site upstream of the coding sequences of $k a t B, k a t C, \operatorname{ahp} C, \operatorname{tr} x B$, and $f n t A$ (Figure 3). No PerR box was found upstream of the $k a t A$ gene, which was down-regulated in response to RNS, the expression of $k a t B$ and $k a t C$ being up-regulated under the probable control of PerR. PerR boxes were also found in the promoter regions of fur and perR, suggesting autoregulation (Figure 3). The nitrosative stress in S. xylosus resulted in a response similar to that for peroxide stress in $S$. aureus, except that transcription of perR was also increased. PerR has been identified as a peroxide-sensing protein (Horsburgh et al., 2001a). It is only the Fe (II)-bound PerR that shows pronounced sensitivity to low levels of peroxide (Lee and Helmann, 2006). In the presence of $\mathrm{H}_{2} \mathrm{O}_{2}$, the iron in PerR leads to formation of a hydroxyl radical which oxidizes histidines at the binding site and prevents DNA binding (Fillat, 2014). In S. aureus, addition of $\mathrm{H}_{2} \mathrm{O}_{2}$ results in increased transcription of most of the PerR regulon except for fur and perR itself (Horsburgh et al., 2001a). As already mentioned above, Fur was inactivated by nitrosative stress and consequently transcription of the Fur regulon was increased, resulting in iron uptake. Elevated iron concentration could affect the distribution between the two forms of PerR, PerR-Fe, which is sensitive to oxidation, and the less sensitive PerR-Mn (Horsburgh et al., 2001a), and thus will induce the PerR regulon thereby keeping the system going (Figure 4). It is worth noting that the gene $m n t H$ encoding the transport of manganese was up-regulated in S. xylosus in the presence of RNS. Mn (II) is important for detoxification because it has a higher reduction potential than Fe (II), and it can function as an antioxidant, unlike iron, which is a pro-oxidant metal (Gaupp et al., 2012).

\section{CARBOHYDRATE TRANSPORT AND METABOLISM}

Glucose $(0.5 \%)$ added to the two meat batches supported the growth of $S$. xylosus for up to $24 \mathrm{~h}$. Glycogen from meat could therefore be a source of glucose and ATP from meat could be a source of ribose and contribute to energy production (Chaillou et al., 2005). Indeed, genes encoding enzymes involved in the Embden-Meyerhof-Parnas (EMP) and the pentose phosphate (PP) pathways were modulated at $t_{24 h}$ and $t_{72 h}$ in the presence of RNS (Table 1) (Figure 4). Each of these pathways has its own function. The EMP pathway (combined with the tricarboxylic acid cycle) is the general route for glucose catabolism and energy formation in the cell, while the PP pathway plays a crucial role in redox metabolism (Kleijn et al., 2006). Four genes (SXYL_02255, SXYL_00253, SXYL_00278, SXYL_00626) encoding phosphotransferase systems (PTS) that catalyze the concomitant uptake and phosphorylation of carbohydrates were modulated (Table 1). The two genes paralogs (SXYL_02255, SXYL_00626) coding for a PTS for alpha-glucoside and the gene (SXYL_00278) coding for a fructose-specific PTS system were up-regulated at $t_{24 h}$, while the gene SXYL_00253 was down-regulated (Table 1). Five other genes (malA, pgi, fbp, iolJ, fda) of the EMP and/or PP pathway were also up-regulated (Table 1). Genes encoding enzymes involved in the uptake and metabolism of two substrates (ribose, arabinose) were modulated by RNS (Table 1). Three of them coding for the ribose $\mathrm{ABC}$ transporter $(r b s B$, $r b s C$, $r b s D)$ were upregulated at $\mathrm{t}_{24 \mathrm{~h}}$ (Figure 4). For arabinose metabolism, the genes $\operatorname{araT}$, $\operatorname{ara} A$ and $a r a D$ were down-regulated in the presence of RNS (Table 1). These genes belong to a cluster of five genes (araRB$D A T)$ that encode proteins for uptake of arabinose and conversion to D-xylulose-5P, which can enter the pentose phosphate pathway (Siezen et al., 2008; Passerini et al., 2013). This cluster has not yet been characterized in Staphylococcus. Moreover, the presence of RNS modulated the transcription of two genes (araB1, araB2) 
encoding ribulokinases involved in the pentose interconversion (Table 1).

Because of the importance of these two metabolic pathways, staphylococci have regulators that sense the availability of these metabolites. Nitrosative stress can alter enzymatic activity resulting in changes in metabolite concentrations and redox balance; these changes will induce the response of these regulators. One form of carbon catabolite repression relying on a transcriptional regulator termed CcpA was up-regulated in S. xylosus in the presence of RNS at $\mathrm{t}_{24 \mathrm{~h}}$ (Table $\mathbf{1}$ ). This regulator requires the corepressor P-Ser-HPr to bind efficiently to its operator sequence cre (catabolite responsive element) (Brückner and Titgemeyer, 2002). In our study, the gene coding for the co-repressor was not modulated.

\section{AMINO ACID TRANSPORT AND METABOLISM}

Transcript levels of eight genes involved in the metabolism of branched-chain amino acids ( $i l v$, leu genes co-localized) and one involved in their transport (brnQ-1) were found to be downregulated in S. xylosus in the presence of RNS (Table 1, Figure 4). In fermented sausages, catabolism of branched-chain amino acids (leucine, isoleucine, valine) results in methyl aldehydes, alcohols and acids involved in flavor (Stahnke, 1995). S. xylosus plays a fundamental role in this metabolism (Stahnke, 1999). Nitrate or nitrite was found to inhibit the degradation of leucine by S. xylosus in meat extract and in laboratory media (Moller et al., 1998; Olesen et al., 2004). This inhibition could be explained by the down-regulation of several genes involved in this metabolism.

Five genes involved in glycine/serine/threonine metabolism were also modulated (Table 1). Three of these genes organized in a cluster $(g c v T, g c v P A, g c v P B)$ were up-regulated while two genes (sdaAA1, sdaAB1) coding for two subunits of the enzyme L-serine dehydratase, which belongs to the iron sulfur-dependent L-serine dehydratase family, were down-regulated in S. xylosus in the presence of RNS (Figure 4).

Sulfur-containing amino acids such as methionine and aromatic amino acids (tryptophan, phenylalanine, and tyrosine) can be oxidized during nitrosative stress (Gaupp et al., 2012). In our conditions, one gene (SXYL_00012) encoding a protein involved in methionine synthesis and 12 genes coding for proteins involved in aromatic amino acid synthesis were modulated (Table 1). Seven genes ( $\operatorname{trp} A$ to $\operatorname{trp} G$ ) encoding enzymes involved in tryptophan synthesis were organized in one cluster in S. xylosus as reported for most Gram-positive bacteria (Gutierrez-Preciado et al., 2005). Six of these genes and the gene SXYL_01128 encoding a DAHP synthase-chorismate mutase were down-regulated in our conditions (Table 1). Nitrosative stress can also modulate the expression of genes involved in sulfur-containing amino acids synthesis (Figure 4).

Transcript levels of 11 genes encoding enzymes involved in the urea cycle and metabolism of amino groups were modulated in S. xylosus in the presence of RNS (Table 1). Four of them (rocD1, $\left.\arg C, \operatorname{argB}, \mathrm{SXYL} \_02450\right)$ coding for enzymes involved in the metabolism of ornithine were down-regulated. The gene ans $A$ coding for an enzyme involved in aspartate metabolism, which can fuel the urea cycle, the gene $\arg G$ coding for a urea cycle enzyme and six genes (ure) coding for urease were up-regulated. Urease activity generates ammonium which is a source of nitrogen, but ammonium ions can also alkalinize the cytoplasm and contribute to the $\Delta \mathrm{pH}$ component of the membrane potential, or the ammonia molecule can diffuse from the cells (Jose et al., 1994; Burne and Chen, 2000). Urease activity can furnish S. xylosus with ammonium and protect it against the acid $\mathrm{pH}$ of the meat model ( $\mathrm{pH}$ 5.7), but in our conditions there was no difference in $\mathrm{pH}$ with or without nitrate and nitrite.

Transcript levels of four genes (ampA, SXYL_01931, SXYL_01348, dapE) encoding peptidases with metallopeptidase activity were found to be up-regulated (Table 1). The gene SXYL_01931 encodes an oligoendopeptidase F. The S. aureus corresponding gene was up-regulated after vancomycin treatment or after exposure to $\mathrm{AgNO}_{3}$, which caused oxidative stress (Kuroda et al., 2003; Smith et al., 2012). The cytosol aminopeptidase encoded by the gene ampA (DQ498891) has already been identified in the cell envelope fraction of $S$. xylosus (Planchon et al., 2007). This aminopeptidase binds manganese ions, and it is noteworthy that the expression of the gene $m n t H$ involved in manganese transport was also up-regulated.

Osmotolerance is one of the characteristic features of staphylococci. They can import osmoprotectants by several transport systems (Kuroda et al., 2005). In our study, the cluster opuC (opu$C A B C D$ ) encoding a glycine betaine/carnitine/choline $\mathrm{ABC}$ transporter was down-regulated at $\mathrm{t}_{24 \mathrm{~h}}$, but the opuCC and opuCD genes were up-regulated at $\mathrm{t}_{72 \mathrm{~h}}$ (Table 1 ). This late up-regulation may indicate a modification of the osmotic pressure. In contrast, the gene opuDl coding for an uptake system of glycine betaine was down-regulated over time in the presence of RNS (Table 1). The down-regulation of $o p u D$ has already been reported in S. aureus subject to combined oxidative and nitrosative stresses (Nobre and Saraiva, 2013). The transporters OpuC and OpuD may respond differently to osmotic environments, but it is not clear why these genes are modulated in our conditions.

\section{ENERGY PRODUCTION AND CONVERSION}

The gene atpD coding for one subunit of ATPase synthase was down-regulated at $\mathrm{t}_{24 \mathrm{~h}}$ in the presence of RNS (Table 1). ATPase synthase genes were down-regulated in Desulfovibrio vulgaris after nitrite stress (He et al., 2006). These results suggest that the electron flow was likely shifted from respiratory phosphorylation to nitrate reduction (He et al., 2006).

In our study, five $\mathrm{Na}^{+} / \mathrm{H}^{+}$antiporter systems were modulated by addition of nitrate and nitrite: either encoded by single genes (SXYL_00623, SXYL_00425, nhaC) or by clusters of genes ( $m n h$ ) (Table 1, Figure 4). Sodium proton antiporters are ubiquitous membrane proteins involved in cell energetics and play a primary role in the homeostasis of intracellular $\mathrm{pH}$ and cellular $\mathrm{Na}^{+}$content, the establishment of an electrochemical potential of $\mathrm{Na}^{+}$and cell volume. Nine different $\mathrm{Na}^{+} / \mathrm{H}^{+}$antiporters have been identified in Gram-positive and Gram-negative bacteria (Majernik et al., 2001; Lorca et al., 2007). Bacteria have several antiporters catalyzing ostensibly similar reactions and the contribution of each antiporter is not yet established. Antiporter Mnh belongs to the cation/proton antiporter-3 (Mrp) family (Swartz et al., 2007). Mrp antiporters require six or seven genes for full activity and are highly conserved. Two Mnh antiporters encoded by two 
operon paralogs ( $m n h, m n h 2)$ of seven genes have been described in S. aureus (Hiramatsu et al., 1998; Swartz et al., 2007). Similarly, seven genes ( $m n h A$ to $m n h G$ ) are also present in the two S. xylosus $m n h$ cluster paralogs. In the $m n h$ cluster, only $m n h G$ was upregulated in $S$. xylosus at $\mathrm{t}_{72 \mathrm{~h}}$, while in the $m n h 2$ cluster, five genes (mnh2ADEFG) were down-regulated at $\mathrm{t}_{24 \mathrm{~h}}$ (Table 1, Figure 4). The expression of $n h a C$ coding for the $\mathrm{Na}^{+} / \mathrm{H}^{+}$antiporter $\mathrm{NhaC}$ of $S$. xylosus was up-regulated in the presence of RNS at $t_{24}$ and $t_{72 h}$ (Table 1). The modulation by RNS of genes encoding $\mathrm{Na}^{+} / \mathrm{H}^{+}$antiporters has not yet been described. But stresses such as $\mathrm{pH}$, salt, temperature and interplay between these stresses can regulate the level of expression and activity of these antiporters (Padan et al., 2005). Further studies are required to define the specific mechanisms that modulate the efficacy of the antiporters and in some cases their capacity to catalyze multiple activities.

\section{CELL WALL/MEMBRANE BIOGENESIS}

Transcript levels of four genes ( $d l t \mathrm{~A}, d l t B, d l t C, d l t D)$ involved in D-alanylation of teichoic acids were down-regulated in S. xylosus in the presence of RNS (Table 1, Figure 4). These four genes are organized in an operon (AF032440) (Peschel et al., 1999). Esterification of D-alanine to teichoic acids has pleiotropic effects such as regulation of autolysins, binding of cations $\left(\mathrm{Na}^{+}, \mathrm{Mg}^{2+}\right.$, $\mathrm{Ca}^{2+}$ ) to the cell envelope and resistance to antimicrobial cationic peptides and proteins (Neuhaus and Baddiley, 2003; Schneewind and Missiakas, 2014). In S. aureus, the degree of D-alanylation depends on the environmental conditions, and decreases with increase in $\mathrm{pH}$, temperature or salt (Neuhaus and Baddiley, 2003). Moreover, dlt expression is repressed in response to $\mathrm{Na}^{+}, \mathrm{Mg}^{2+}$, and $\mathrm{Ca}^{2+}$ (Koprivnjak et al., 2006). It is noteworthy that in our conditions the gene $m g t E$ coding for a protein involved in magnesium transport and the gene $n h a C$ coding for an antiporter involved in the uptake of $\mathrm{Na}^{+}$were up-regulated in S. xylosus.

\section{DNA SYNTHESIS AND REPAIR}

Transcript levels of three genes encoding ribonucleoside reductases (RNRs) were modulated (Table 1). Two of them ( $n d r I, n r d F$ ) were up-regulated, while $n r d G$ was down-regulated. RNRs are enzymes essential for the synthesis of deoxyribonucleotides, the precursors of DNA synthesis or repair (Figure 4). They catalyze the reduction of the four ribonucleotides to maintain a pool of deoxyribonucleotides during the cell cycle. Three classes of RNRs are known (Rabinovitch et al., 2010). S. aureus contains Class Ib and class III RNRs, which are essential for aerobic and anaerobic growth, respectively (Masalha et al., 2001). Class III RNRs are encoded by $n r d D$ and $n r d G$ genes in S. aureus (Masalha et al., 2001). Similar organization is found in the genome of S. xylosus, but $n r d D$ is truncated, i.e., a pseudogene. It is worth noting that two truncated parts of $n r d D$ (SXYL_00148; SXYL_00149) were transcriptionally active and were also down-regulated, as mentioned for $n d r G$. The class Ib NrdEF is encoded by the $n r d E$ and $n r d F$ genes, which form an operon containing a third gene $n r d I$ which overlaps with $n r d E$ in S. aureus (Masalha et al., 2001). We observed the same cluster of three genes nrdIEF in the S. xylosus genome. In S. aureus, NrdEF are able to function with thioredoxin reductase as the donor of hydrogen (Rabinovitch et al., 2010). In our study, the expression of the gene $\operatorname{tr} x B$ encoding thioredoxin reductase was up-regulated (Table 1). In E. coli, expression of the nrdHIEF operon is triggered in response to oxidative stress (Monje-Casas et al., 2001). This induction is mediated by the inactivation of Fur (Martin and Imlay, 2011). In our study, as already stated, nitrosative stress inactivated Fur in S. xylosus, and a similar mechanism could explain the up-regulation of $n r d I$ and $n r d F$ (Figure 4).

Four genes $(f o l D$, folB folK, folP) encoding proteins involved in the synthesis of folate were up-regulated in S. xylosus in the presence of RNS (Table 1). As S. xylosus C2a is able to grow in a minimal medium including only three vitamins (thiamine, nicotinic acid, and biotin) (Fiegler and Brückner, 1997), we can suppose that it has the capacity to synthesize folate. Folate is required as a cofactor in one-carbon-atom transfer reactions, including methionine, purine, and thymine syntheses, and it has been proposed as an antioxidant that scavenges peroxyl, azide and hydroxyl radicals (Huang et al., 2004; Rossi et al., 2011).

Two genes, $n$th encoding an endonuclease type III and $u v r C$ encoding UvrABC system protein C, involved in DNA excision repair were up-regulated in S. xylosus in the presence of RNS (Table 1, Figure 4). In E. coli, pyrimidine lesions generated by free radical $\mathrm{HO}$ are recognized by endonuclease types III and VIII (Wallace, 1988). The complex UvrABC is involved in nucleotide excision and repair, and the genes $u v r A B C$ are reported in S. aureus (Ambur et al., 2009) and also present as a cluster in $S$. xylosus.

\section{POST-TRANSLATIONAL MODIFICATION, PROTEIN TURNOVER, CHAPERONES}

Chaperones and ATP-dependent proteases play a major role in bacterial survival under conditions of stress where proteins tend to unfold and aggregate. In our conditions, nitrosative stress leads to an increase in the expression of $h s l O$ (heat shock protein 33 homolog), clpC (ATP-dependent Clp protease ATP-binding subunit clpC) and groS, (Table 1, Figure 4). The heat shock protein Hsp33 was first found to be induced by heat shock, but it has been discovered that it requires both unfolding as well oxidative conditions to become active (Ilbert et al., 2007). Hsp 33 contains a bound $\mathrm{Zn}^{2+}$ ion coordinated by four cysteines, and under oxidizing conditions two disulfide bonds are formed involving the reactive cysteines, while under reducing conditions zinc is bound to the reactive cysteines and the protein is inactive. It is worth noting that the gene $c z r A$ encoding a zinc and cobalt repressor was up-regulated in S. xylosus (Table 1), as already described for S. aureus during nitrosative stress (Nobre and Saraiva, 2013). The gene $c l p C$ has been shown to be induced in heat-shocked cells in S. aureus (Frees et al., 2004). It is noteworthy that the expression of the heat-inducible transcription repressor hcrA was down-regulated in S. xylosus in the presence of RNS. In S. aureus, HrcA regulator is required to repress transcription of groS and is modulated by the thiol-specific oxidant diamide (Wolf et al., 2008).

\section{CONCLUSIONS}

In this study, determination of the global gene expression of S. xylosus in situ in meat in the presence of nitrate and nitrite at the levels used in the meat industry has allowed us to unravel the 
adaptive response of this bacterium to nitrosative stress. S. xylosus counteracts nitrosative stress by developing several oxidative stress resistance mechanisms such as modulation of the expression of genes involved in iron homeostasis mostly under the control of Fur, detoxifying enzymes mostly under the control of PerR, and DNA and protein repairs. Nitrosative stress could alter Fe-S clusters and sulfur-containing proteins and S. xylosus adapts to these changes in metabolite concentrations by modulating the expression of several genes involved in carbon and nitrogen metabolism, energy production and cell wall biogenesis. Our results offer the sole data set for the response of a foodassociated bacterium when exposed to nitrate and nitrite in meat. Despite the low concentration of nitrate and nitrite used, a significant change in the $S$. xylosus gene expression was observed. The strategies to reduce the input of nitrate and nitrite in meat products should also take into account the potential impact on bacterial starter cultures.

\section{ACKNOWLEDGMENTS}

Aurore Vermassen is a $\mathrm{PhD}$ Research Fellow funded by the French "Ministère de l'Education Nationale, de l'Enseignement Supérieur et de la Recherche (M.E.N.E.S.R.)." The microarray development was financially supported by the ANR project "Genoferment" ANR-05-PNRA-020. We are grateful to Pierre Micheau for his assistance in data organization and to Souad Christieans (ADIV Viande Performances) for her assistance in nitrate-nitrite measurements in meat. We would like to thank Jean-Paul Chacornac for valuable technical assistance with meat inoculation and sampling. The authors are grateful to David Marsh for correcting our English.

\section{SUPPLEMENTARY MATERIAL}

The Supplementary Material for this article can be found online at: http://www.frontiersin.org/journal/10.3389/fmicb. 2014.00691/abstract

\section{REFERENCES}

Ambur, O. H., Davidsen, T., Frye, S. A., Balasingham, S. V., Lagesen, K., Rognes, T., et al. (2009). Genome dynamics in major bacterial pathogens. FEMS Microbiol. Rev. 33, 453-470. doi: 10.1111/j.1574-6976.2009.00173.x

Andrews, S. C. (1998). Iron storage in bacteria. Adv. Microb. Physiol. 40, 281-351. doi: 10.1016/S0065-2911(08)60134-4

Barrière, C., Brückner, R., Centeno, D., and Talon, R. (2002). Characterisation of the katA gene encoding a catalase and evidence for at least a second catalase activity in Staphylococcus xylosus, bacteria used in food fermentation. FEMS Microbiol. Lett. 216, 277-283. doi: 10.1016/S0378-1097(02) 01030-3

Barrière, C., Brückner, R., and Talon, R. (2001a). Characterization of the single superoxide dismutase of Staphylococcus xylosus. Appl. Environ. Microbiol. 67, 4096-4104. doi: 10.1128/AEM.67.9.4096-4104.2001

Barrière, C., Leroy-Sétrin, S., and Talon, R. (2001b). Characterization of catalase and superoxide dismutase in Staphylococcus carnosus 833 strain. J. Appl. Microbiol. 91, 514-519. doi: 10.1046/j.1365-2672.2001.01411.x

Beasley, F. C., and Heinrichs, D. E. (2010). Siderophore-mediated iron acquisition in the staphylococci. J. Inorg. Biochem. 104, 282-288. doi: 10.1016/j.jinorgbio.2009.09.011

Blaiotta, G., Fusco, V., Ercolini, D., Pepe, O., and Coppola, S. (2010). Diversity of Staphylococcus species strains based on partial kat (catalase) gene sequences and design of a PCR-restriction fragment length polymorphism assay for identification and differentiation of coagulase-positive species (S. aureus, S. delphini, S. hyicus, S. intermedius, S. pseudintermedius, and S. schleiferi subsp. coagulans). J. Clin. Microbiol. 48, 192-201. doi: 10.1128/JCM.00542-09
Brückner, R., and Titgemeyer, F. (2002). Carbon catabolite repression in bacteria: choice of the carbon source and autoregulatory limitation of sugar utilization. FEMS Microbiol. Lett. 209, 141-148. doi: 10.1016/S0378-1097(02)00559-1

Burne, R. A., and Chen, Y. Y. (2000). Bacterial ureases in infectious diseases. Microbes Infect. 2, 533-542. doi: 10.1016/S1286-4579(00)00312-9

Cammack, R., Joannou, C. L., Xiao-Yuan, C., Martinez, C. T., Maraj, S. R., and Hughes, M. N. (1999). Nitrite and nitrosyl compounds in food preservation. Biochim. Biophys. Acta 1411, 475-488. doi: 10.1016/S0005-2728(99)00033-X

Chaillou, S., Champomier-Vergès, M. C., Cornet, M., Crutz-Le Coq, A. M., Dudez, A. M., Martin, V., et al. (2005). The complete genome sequence of the meat-borne lactic acid bacterium Lactobacillus sakei 23K. Nat. Biotechnol. 23 , 1527-1533. doi: 10.1038/nbt1160

Coton, E., Desmonts, M.-H., Leroy, S., Coton, M., Jamet, E., Christieans, S., et al. (2010). Biodiversity of coagulase-negative Staphylococci in French cheeses, dry fermented sausages, processing environments and clinical samples. Int. J. Food Microbiol. 137, 221-229. doi: 10.1016/j.ijfoodmicro.2009.11.023

D’Autréaux, B., Touati, D., Bersch, B., Latour, J. M., and Michaud-Soret, I. (2002). Direct inhibition by nitric oxide of the transcriptional ferric uptake regulation protein via nitrosylation of the iron. Proc. Natl. Acad. Sci. U.S.A. 99, 16619-16624. doi: 10.1073/pnas.252591299

Demeyer, D., Raemaekers, M., Rizzo, A., Holck, A., De Smedt, A., Ten Brink, B., et al. (2000). Control of bioflavour and safety in fermented sausages: first results of a European project. Food Res. Int. 33, 171-180. doi: 10.1016/S09639969(00)00031-4

Ezraty, B., Aussel, L., and Barras, F. D. R. (2005). Methionine sulfoxide reductases in prokaryotes. Biochim. Biophys. Acta 1703, 221-229. doi: 10.1016/j.bbapap.2004.08.017

Fedtke, I., Kamps, A., Krismer, B., and Götz, F. (2002). The nitrate reductase and nitrite reductase operons and the narT gene of Staphylococcus carnosus are positively controlled by the novel two-component system NreBC. J. Bacteriol. 184, 6624-6634. doi: 10.1128/JB.184.23.6624-6634.2002

Fiegler, H., and Brückner, R. (1997). Identification of the serine acetyltransferase gene of Staphylococcus xylosus. FEMS Microbiol. Lett. 148, 181-187. doi: 10.1111/j.1574-6968.1997.tb10286.x

Fillat, M. F. (2014). The FUR (ferric uptake regulator) superfamily: diversity and versatility of key transcriptional regulators. Arch. Biochem. Biophys. 546, 41-52. doi: 10.1016/j.abb.2014.01.029

Frees, D., Chastanet, A., Qazi, S., Sorensen, K., Hill, P., Msadek, T., et al. (2004). Clp ATPases are required for stress tolerance, intracellular replication and biofilm formation in Staphylococcus aureus. Mol. Microbiol. 54, 1445-1462. doi: 10.1111/j.1365-2958.2004.04368.x

García-Varona, M., Santos, E. M., Jaime, I., and Rovira, J. (2000). Characterisation of Micrococcaceae isolated from different varieties of chorizo. Int. J. Food Microbiol. 54, 189-195. doi: 10.1016/S0168-1605(99)00192-0

Gaupp, R., Ledala, N., and Somerville, G. A. (2012). Staphylococcal response to oxidative stress. Front. Cell. Infect. Microbiol. 2:33. doi: 10.3389/fcimb.2012.00033

Gøtterup, J., Olsen, K., Knöchel, S., Tjener, K., Stahnke, L. H., and Møller, J. K. S. (2007). Relationship between nitrate/nitrite reductase activities in meat associated staphylococci and nitrosylmyoglobin formation in a cured meat model system. Int. J. Food Microbiol. 120, 303-310. doi: 10.1016/j.ijfoodmicro.2007. 08.034

Gutierrez-Preciado, A., Jensen, R. A., Yanofsky, C., and Merino, E. (2005). New insights into regulation of the tryptophan biosynthetic operon in gram-positive bacteria. Trends Genet. 21, 432-436. doi: 10.1016/j.tig.2005.06.001

Haley, K. P., and Skaar, E. P. (2012). A battle for iron: host sequestration and Staphylococcus aureus acquisition. Microbes Infect. 14, 217-227. doi: 10.1016/j.micinf.2011.11.001

Hammer, N. D., and Skaar, E. P. (2011). Molecular mechanisms of Staphylococcus aureus iron acquisition. Annu. Rev. Microbiol. 65, 129-147. doi: 10.1146/ annurev-micro-090110-102851

Hammes, W. P. (2012). Metabolism of nitrate in fermented meats: the characteristic feature of a specific group of fermented foods. Food Microbiol. 29, 151-156. doi: 10.1016/j.fm.2011.06.016

Hassan, H. M., and Troxell, B. (2013). Transcriptional regulation by Ferric Uptake Regulator (Fur) in pathogenic bacteria. Front. Cell. Infect. Microbiol. 3:59. doi: 10.3389/fcimb.2013.00059

He, Q., Huang, K. H., He, Z., Alm, E. J., Fields, M. W., Hazen, T. C., et al. (2006). Energetic consequences of nitrite stress in Desulfovibrio vulgaris Hildenborough, 
inferred from global transcriptional analysis. Appl. Environ. Microbiol. 72, 4370-4381. doi: 10.1128/AEM.02609-05

Hiramatsu, T., Kodama, K., Kuroda, T., Mizushima, T., and Tsuchiya, T. (1998). A putative multisubunit $\mathrm{Na}^{+} / \mathrm{H}^{+}$antiporter from Staphylococcus aureus. J. Bacteriol. 180, 6642-6648.

Hochgräfe, F., Wolf, C., Fuchs, S., Liebeke, M., Lalk, M., Engelmann, S., et al. (2008). Nitric oxide stress induces different responses but mediates comparable protein thiol protection in Bacillus subtilis and Staphylococcus aureus. J. Bacteriol. 190, 4997-5008. doi: 10.1128/JB.01846-07

Honikel, K. O. (2008). The use and control of nitrate and nitrite for the processing of meat products. Meat Sci. 78, 68-76. doi: 10.1016/j.meatsci.2007.05.030

Horsburgh, M. J., Clements, M. O., Crossley, H., Ingham, E., and Foster, S. J. (2001a). PerR controls oxidative stress resistance and iron storage proteins and is required for virulence in Staphylococcus aureus. Infect. Immun. 69, 3744-3754. doi: 10.1128/IAI.69.6.3744-3754.2001

Horsburgh, M. J., Ingham, E., and Foster, S. J. (2001b). In Staphylococcus aureus, Fur is an interactive regulator with PerR, contributes to virulence, and is necessary for oxidative stress resistance through positive regulation of catalase and iron homeostasis. J. Bacteriol. 183, 468-475. doi: 10.1128/JB.183.2.468-475.2001

Huang, R. F., Yaong, H. C., Chen, S. C., and Lu, Y. F. (2004). In vitro folate supplementation alleviates oxidative stress, mitochondria-associated death signalling and apoptosis induced by 7-ketocholesterol. Br. J. Nutr. 92, 887-894. doi: 10.1079/BJN20041259

Ilbert, M., Horst, J., Ahrens, S., Winter, J., Graf, P. C., Lilie, H., et al. (2007). The redox-switch domain of Hsp33 functions as dual stress sensor. Nat. Struct. Mol. Biol. 14, 556-563. doi: 10.1038/nsmb1244

Jose, J., Schafer, U. K., and Kaltwasser, H. (1994). Threonine is present instead of cysteine at the active site of urease from Staphylococcus xylosus. Arch. Microbiol. 161, 384-392. doi: 10.1007/BF00288947

Kleijn, R. J., van Winden, W. A., Ras, C., van Gulik, W. M., Schipper, D., and Heijnen, J. J. (2006). 13C-labeled gluconate tracing as a direct and accurate method for determining the pentose phosphate pathway split ratio in Penicillium chrysogenum. Appl. Environ. Microbiol. 72, 4743-4754. doi: 10.1128/AEM.02955-05

Kloos, W. E., Zimmerman, R. J., and Smith, R. F. (1976). Preliminary studies on the characterization and distribution of Staphylococcus and Micrococcus species on animal skin. Appl. Environ. Microbiol. 31, 53-59.

Koprivnjak, T., Mlakar, V., Swanson, L., Fournier, B., Peschel, A., and Weiss, J. P. (2006). Cation-induced transcriptional regulation of the dlt operon of Staphylococcus aureus. J. Bacteriol. 188, 3622-3630. doi: 10.1128/JB.188.10.3622-3630.2006

Kuroda, M., Kuroda, H., Oshima, T., Takeuchi, F., Mori, H., and Hiramatsu, K. (2003). Two-component system VraSR positively modulates the regulation of cell-wall biosynthesis pathway in Staphylococcus aureus. Mol. Microbiol. 49, 807-821. doi: 10.1046/j.1365-2958.2003.03599.x

Kuroda, M., Yamashita, A., Hirakawa, H., Kumano, M., Morikawa, K., Higashide, M., et al. (2005). Whole genome sequence of Staphylococcus saprophyticus reveals the pathogenesis of uncomplicated urinary tract infection. Proc. Natl. Acad. Sci. U.S.A. 102, 13272-13277. doi: 10.1073/pnas.0502 950102

Lee, J. W., and Helmann, J. D. (2006). The PerR transcription factor senses $\mathrm{H}_{2} \mathrm{O}_{2}$ by metal-catalysed histidine oxidation. Nature 440, 363-367. doi: 10.1038/nature 04537

Leroy, F., Verluyten, J., and De Vuyst, L. (2006). Functional meat starter cultures for improved sausage fermentation. Int. J. Food Microbiol. 106, 270-285. doi: 10.1016/j.ijfoodmicro.2005.06.027

Lorca, G. L., Barabote, R. D., Zlotopolski, V., Tran, C., Winnen, B., Hvorup, R. N., et al. (2007). Transport capabilities of eleven gram-positive bacteria: comparative genomic analyses. Biochim. Biophys. Acta 6, 17. doi: 10.1016/j.bbamem.2007.02.007

Majernik, A., Gottschalk, G., and Daniel, R. (2001). Screening of environmental DNA libraries for the presence of genes conferring $\mathrm{Na}^{(+)}\left(\mathrm{Li}^{(+)}\right) / \mathrm{H}^{(+)}$ antiporter activity on Escherichia coli: characterization of the recovered genes and the corresponding gene products. J. Bacteriol. 183, 6645-6653. doi: 10.1128/JB.183.22.6645-6653.2001

Martin, J. E., and Imlay, J. A. (2011). The alternative aerobic ribonucleotide reductase of Escherichia coli, NrdEF, is a manganese-dependent enzyme that enables cell replication during periods of iron starvation. Mol. Microbiol. 80, 319-334. doi: 10.1111/j.1365-2958.2011.07593.x
Masalha, M., Borovok, I., Schreiber, R., Aharonowitz, Y., and Cohen, G. (2001). Analysis of transcription of the Staphylococcus aureus aerobic class Ib and anaerobic class III ribonucleotide reductase genes in response to oxygen. J. Bacteriol. 183, 7260-7272. doi: 10.1128/JB.183.24.7260-7272.2001

Mauriello, G., Casaburi, A., Blaiotta, G., and Villani, F. (2004). Isolation and technological properties of coagulase negative staphylococci from fermented sausages of Southern Italy. Meat Sci. 67, 149-158. doi: 10.1016/j.meatsci.2003. 10.003

Moller, J. K., Hinrichsen, L. L., and Andersen, H. J. (1998). Formation of amino acid (L-leucine, L-phenylalanine) derived volatile flavour compounds by Moraxella phenylpyruvica and Staphylococcus xylosus in cured meat model systems. Int. J. Food Microbiol. 42, 101-117. doi: 10.1016/S0168-1605(98) 00069-5

Monje-Casas, F., Jurado, J., Prieto-Ãlamo, M.-J., Holmgren, A., and Pueyo, C. (2001). Expression analysis of the nrdHIEF operon from Escherichia coli: condition that trigger the transport level in vivo. J. Biol. Chem. 276, 18031-18037. doi: 10.1074/jbc.M011728200

Morrissey, J. A., Cockayne, A., Brummell, K., and Williams, P. (2004). The staphylococcal ferritins are differentially regulated in response to iron and manganese and via PerR and Fur. Infect. Immun. 72, 972-979. doi: 10.1128/IAI.72.2.972979.2004

Moskovitz, J. (2005). Methionine sulfoxide reductases: ubiquitous enzymes involved in antioxidant defense, protein regulation, and prevention of aging-associated diseases. Biochim. Biophys. Acta 1703, 213-219. doi: 10.1016/j.bbapap.2004.09.003

Mukhopadhyay, P., Zheng, M., Bedzyk, L. A., LaRossa, R. A., and Storz, G. (2004). Prominent roles of the NorR and Fur regulators in the Escherichia coli transcriptional response to reactive nitrogen species. Proc. Natl. Acad. Sci. U.S.A. 101, 745-750. doi: 10.1073/pnas.0307741100

Nagase, N., Sasaki, A., Yamashita, K., Shimizu, A., Wakita, Y., Kitai, S., et al. (2002). Isolation and species distribution of staphylococci from animal and human skin. J. Vet. Med. Sci. 64, 245-250. doi: 10.1292/jvms.64.245

Neubauer, H., and Götz, F. (1996). Physiology and interaction of nitrate and nitrite reduction in Staphylococcus carnosus. J. Bacteriol. 178, 2005-2009.

Neubauer, H., Pantel, I., and Götz, F. (1999). Molecular characterization of the nitrite-reducing system of Staphylococcus carnosus. J. Bacteriol. 181, 1481-1488.

Neuhaus, F. C., and Baddiley, J. (2003). A continuum of anionic charge: structures and functions of d-alanyl-teichoic acids in gram-positive bacteria. Microbiol. Mol. Biol. Rev. 67, 686-723. doi: 10.1128/MMBR.67.4.686723.2003

Nobre, L. S., and Saraiva, L. M. (2013). Effect of combined oxidative and nitrosative stresses on Staphylococcus aureus transcriptome. Appl. Microbiol. Biotechnol. 97, 2563-2573. doi: 10.1007/s00253-013-4730-3

Olesen, P. T., Stahnke, L., and Talon, R. (2004). Effect of ascorbate, nitrate and nitrite on the amount of flavour compounds produced from leucine by Staphylococcus xylosus and Staphylococcus carnosus. Meat Sci. 68, 193-200. doi: 10.1016/j.meatsci.2004.02.017

Padan, E., Bibi, E., Ito, M., and Krulwich, T. A. (2005). Alkaline pH homeostasis in bacteria: new insights. Biochim. Biophys. Acta 30, 67-88. doi 10.1016/j.bbamem.2005.09.010

Passerini, D., Coddeville, M., Le Bourgeois, P., Loubière, P., Ritzenthaler, P., Fontagné-Faucher, C., et al. (2013). The carbohydrate metabolism signature of Lactococcus lactis strain A12 reveals its sourdough ecosystem origin. Appl. Environ. Microbiol. 79, 5844-5852. doi: 10.1128/AEM.01560-13

Peschel, A., Otto, M., Jack, R. W., Kalbacher, H., Jung, G., and Götz, F. (1999). Inactivation of the dlt operon in Staphylococcus aureus confers sensitivity to defensins, protegrins, and other antimicrobial peptides. J. Biol. Chem. 274, 8405-8410. doi: $10.1074 /$ jbc.274.13.8405

Pfaffl, M. W. (2001). A new mathematical model for relative quantification in realtime RT-PCR. Nucleic Acids Res. 29, 2002-2007. doi: 10.1093/nar/29.9.e45

Planchon, S., Chambon, C., Desvaux, M., Chafsey, I., Leroy, S., Talon, R., et al. (2007). Proteomic analysis of cell envelope from Staphylococcus xylosus C2a, a coagulase-negative Staphylococcus. J. Proteome Res. 6, 3566-3580. doi: $10.1021 /$ pr070139+

Planchon, S., Desvaux, M., Chafsey, I., Chambon, C., Leroy, S., Hébraud, M., et al. (2009). Comparative subproteome analyses of planktonic and sessile Staphylococcus xylosus C2a: new insight in cell physiology of a coagulasenegative Staphylococcus in biofilm. J. Proteome Res. 8, 1797-1809. doi: 10.1021/ pr8004056 
Rabinovitch, I., Yanku, M., Yeheskel, A., Cohen, G., Borovok, I., and Aharonowitz, Y. (2010). Staphylococcus aureus $\mathrm{NrdH}$ redoxin is a reductant of the class $\mathrm{Ib}$ ribonucleotide reductase. J. Bacteriol. 192, 4963-4972. doi: 10.1128/JB.00539-10

Richardson, A. R., Dunman, P. M., and Fang, F. C. (2006). The nitrosative stress response of Staphylococcus aureus is required for resistance to innate immunity. Mol. Microbiol. 61, 927-939. doi: 10.1111/j.1365-2958.2006.05290.x

Rosenstein, R., Nerz, C., Biswas, L., Resch, A., Raddatz, G., Schuster, S. C., et al. (2009). Genome analysis of the meat starter culture bacterium Staphylococcus carnosus TM300. Appl. Environ. Microbiol. 75, 811-822. doi: 10.1128/AEM. 01982-08

Rossi, M., Amaretti, A., and Raimondi, S. (2011). Folate production by probiotic bacteria. Nutrients 3, 118-134. doi: 10.3390/nu3010118

Saha, R., Saha, N., Donofrio, R. S., and Bestervelt, L. L. (2013). Microbial siderophores: a mini review. J. Basic Microbiol. 53, 303-317. doi: 10.1002/jobm. 201100552

Schneewind, O., and Missiakas, D. (2014). Lipoteichoic acids, phosphatecontaining polymers in the envelope of gram-positive Bacteria. J. Bacteriol. 196, 1133-1142. doi: 10.1128/JB.01155-13

Schwyn, B., and Neilands, J. B. (1987). Universal chemical-assay for the detection and determination of siderophores. Anal. Biochem. 160, 47-56. doi: 10.1016/0003-2697(87)90612-9

Sheldon, J., and Heinrichs, D. (2012). The iron-regulated staphylococcal lipoproteins. Front. Cell. Infect. Microbiol. 2:41. doi: 10.3389/fcimb.2012.00041

Siezen, R. J., Starrenburg, M. J. C., Boekhorst, J., Renckens, B., Molenaar, D., and van Hylckama Vlieg, J. E. T. (2008). Genome-scale genotype-phenotype matching of two Lactococcus lactis isolates from plants identifies mechanisms of adaptation to the plant niche. Appl. Environ. Microbiol. 74, 424-436. doi: 10.1128/AEM.01850-07

Singh, V. K., and Moskovitz, J. (2003). Multiple methionine sulfoxide reductase genes in Staphylococcus aureus: expression of activity and roles in tolerance of oxidative stress. Microbiology 149, 2739-2747. doi: 10.1099/mic.0.26442-0

Smith, A., Rowan, R., McCann, M., and Kavanagh, K. (2012). Exposure of Staphylococcus aureus to silver(I) induces a short term protective response. Biometals 25, 611-616. doi: 10.1007/s10534-012-9549-3

Smith, G. K. (2004). Linear models and empirical bayes methods for assessing differential expression in microarray experiments. Stat. Appl. Genet. Mol. Biol. 3, Article3. doi: 10.2202/1544-6115.1027

Spiro, S. (2007). Regulators of bacterial responses to nitric oxide. FEMS Microbiol. Rev. 31, 193-211. doi: 10.1111/j.1574-6976.2006.00061.x

Stahnke, L. H. (1995). Dried sausages fermented with Staphylococcus xylosus at different temperatures and with different ingredient levels-Part II. Volatile components. Meat Sci. 41, 193-209. doi: 10.1016/0309-1740(94)00069-J

Stahnke, L. H. (1999). Volatiles produced by Staphylococcus xylosus and Staphylococcus carnosus during growth in sausage minces part II. The influence of growth parameters. LWT Food Sci. Technol. 32, 365-371. doi: 10.1006/fstl.19 99.0560

Streker, K., Freiberg, C., Labischinski, H., Hacker, J., and Ohlsen, K. (2005). Staphylococcus aureus NfrA (SA0367) is a flavin mononucleotide-dependent $\mathrm{NADPH}$ oxidase involved in oxidative stress response. J. Bacteriol. 187, 2249-2256. doi: 10.1128/JB.187.7.2249-2256.2005
Swartz, T. H., Ito, M., Ohira, T., Natsui, S., Hicks, D. B., and Krulwich, T. A. (2007). Catalytic properties of Staphylococcus aureus and Bacillus members of the secondary cation/proton antiporter-3 (Mrp) family are revealed by an optimized assay in an Escherichia coli host. J. Bacteriol. 189, 3081-3090. doi: 10.1128/JB.00021-07

Talon, R., and Leroy, S. (2011). Diversity and safety hazards of bacteria involved in meat fermentations. Meat Sci. 89, 303-309. doi: 10.1016/j.meatsci.2011.04.029

Talon, R., Leroy-Sétrin, S., and Fadda, S. (2002). "Bacterial starters involved in the quality of fermented meat products-Chapter 10," in Research Advances in Quality of Meat and Meat Products, ed F. Toldrá (Trivandrum: Research Signpost), 175-191.

Talon, R., Walter, D., Chartier, S., Barrière, C., and Montel, M. C. (1999). Effect of nitrate and incubation conditions on the production of catalase and nitrate reductase by staphylococci. Int. J. Food Microbiol. 52, 47-56. doi: 10.1016/S01681605(99)00127-0

Tavares, A. F., Nobre, L. S., Melo, A. M., and Saraiva, L. M. (2009). A novel nitroreductase of Staphylococcus aureus with S-nitrosoglutathione reductase activity. J. Bacteriol. 191, 3403-3406. doi: 10.1128/JB.00022-09

Tompkin, R. B. (1995). "Nitrite," in Antimicrobials in food, 3rd Edn., eds P. M. Davidson, J. N. Sofos, and A. L. Branen (Boca Raton, FL: CRC Press, Taylor \& Francis Group), 170-221.

Wallace, S. S. (1988). Ap endonucleases and dna glycosylases that recognize oxidative dna damage. Environ. Mol. Mutagen. 12, 431-477. doi: 10.1002/em.2860120411

Wolf, C., Hochgrafe, F., Kusch, H., Albrecht, D., Hecker, M., and Engelmann, S. (2008). Proteomic analysis of antioxidant strategies of Staphylococcus aureus: diverse responses to different oxidants. Proteomics 8, 3139-3153. doi: 10.1002/pmic.200701062

Conflict of Interest Statement: The Review Editor Yves Le Loir declares that, despite being previously involved in a joint funding project with the author Régine Talon, the review process was handled objectively and no conflict of interest exists. The authors declare that the research was conducted in the absence of any commercial or financial relationships that could be construed as a potential conflict of interest.

Received: 01 August 2014; accepted: 22 November 2014; published online: 15 December 2014.

Citation: Vermassen A, de la Foye A, Loux V, Talon $R$ and Leroy $S$ (2014) Transcriptomic analysis of Staphylococcus xylosus in the presence of nitrate and nitrite in meat reveals its response to nitrosative stress. Front. Microbiol. 5:691. doi: 10.3389/ fmicb.2014.00691

This article was submitted to Microbial Physiology and Metabolism, a section of the journal Frontiers in Microbiology.

Copyright (c) 2014 Vermassen, de la Foye, Loux, Talon and Leroy. This is an openaccess article distributed under the terms of the Creative Commons Attribution License (CC BY). The use, distribution or reproduction in other forums is permitted, provided the original author(s) or licensor are credited and that the original publication in this journal is cited, in accordance with accepted academic practice. No use, distribution or reproduction is permitted which does not comply with these terms. 